\title{
EFETIFITAS MUSIK KERONCONG DAN MUSIK JAWA DALAM MENINGKATKAN KUALITAS TIDUR LANSIA YANG MENGALAMI INSOMNIA DI PANTI GRIYA WREDA SURABAYA
}

\author{
Ni Putu Widari *Lintang Sinta Sasanti Taloda** \\ STIKes William Booth Surabaya, Jl. Cimanuk No 20, Surabaya 60241. \\ putu.widari@yahoo.com
}

\begin{abstract}
ABSTRAK
Tujuan penelitian ini yaitu untuk mengetahui perbandingan efektifitas musik keroncong dan musik jawa dalam meningkatkan kualitas tidur lansia yang mengalami insomnia. Design dalam penelitian ini menggunakan pra eksperimen (on-group pre-post design) dengan sampel penghuni Panti Werdha Griya Jambangan sebanyak 12 responden. Sampel dibagi menjadi dua kelompok, yaitu 6 responden untuk terapi musik keroncong dan 6 responden untuk terapi musik jawa. Pengambilan data dengan cara memberikan kuisioner untuk mengetahui tingkat insomnia pada lansia sebelum dilakukan terapi musik keroncong dan terapi musik jawa (10-30 menit). Skala insomnia diukur dengan menggunakan Insomnia Rating Scale. Dalam penelitian ini uji statistik diukur menggunakan uji Wilcoxon. Berdasarkan hasil uji statistik Wilcoxon didapatkan hasil $\mathrm{p}=0,027$ dengan kemaknaan $\mathrm{p}<0,05$ yang berarti $\mathrm{H} 0$ ditolak dan Ha diterima, sehingga terdapat pengaruh antara pre test dan post test pada terapi musik keroncong. Berdasarkan hasil uji statistik Wilcoxon didapatkan hasil $\mathrm{p}=0,068$ dengan kemaknaan $\mathrm{p}>0,05$ yang berarti $\mathrm{H} 0$ diterima sehingga tidak terdapat perbedaan antara pre test dan post test pada terapi musik keroncong pada lansia yang mengalami insomnia. Kesimpulan untuk terapi ini, musik keroncong lebih efektif dibandingkan musik jawa pada lansia yang mengalami insomnia di Panti Werdha Griya Jambangan Surabaya.
\end{abstract}

Kata Kunci : Insomnia, Lansia, Terapi Musik Keroncong, Terapi Musik Jawa

\begin{abstract}
Music therapy is the skill of using music or elements of music by a therapist to Improve, defend, and restore The mental, physical, emotional and Spiritual health of one of them is to use music Therapy of Keroncong and music of Java that is comfortable, soothing, relaxing, structured and universal so that it can bring The elderly increasingly fast to start sleeping. The purpose of this research is to know the effectiveness of Keroncong music and Javanese music to improve the sleep quality of elderly insomnia. The design in this study used pre-experimental (on-group pre-post design) with samples of the occupants of the orphanage Werdha Griya Jambangan as many as 12 respondents. The samples are divided into two groups, which are 6 respondents for Keroncong music therapy and 6 respondents for Javanese music therapy. Data retrieval by giving the questionnaire to know the level of insomnia in the elderly before doing Keroncong music therapy and Javanese music therapy (10-30 minutes). The insomnia scale is measured using Insomnia Rating Scale. In this research statistical test measured using test paired-sample t test. Based on the results of the statistical test paired sample T-Test obtained the result of $p=0.000$ with the significance of $\mathrm{P}<0.05$ which means $\mathrm{H} 0$ rejected and Ha accepted, so there is an influence between the pre test and post test on Keroncong music therapy. Based on the results of the statistical test paired sample T-Test obtained the result of $\mathrm{p}=0.069$ with the significance of $\mathrm{P}<0.05$ which means $\mathrm{H} 0$ rejected and $\mathrm{Ha}$ accepted, so there is an influence between the pre test and post test on Javanese music therapy in the elderly who are experiencing
\end{abstract}


insomnia. Conclusion for this therapy, Keroncong music is more effective than Javanese music in the elderly who have insomnia in the orphanage Werdha Griya Jambangan Surabaya.

Keywords: Insomnia, elderly, Keroncong music therapy, Javanese music therapy

\section{PENDAHULUAN}

Proses menua merupakan suatu proses menghilangnya kemampuan pada jaringan lunak secara perlahan-lahan untuk memperbaiki diri maupun mempertahankan struktur dan fungsi normalnya sehingga tidak dapat bertahan terhadap infeksi dan memperbaiki kerusakan yang diderita (Constaindes dalam Darmojo \& Martono 2006). Beberapa perubahan-perubahan fisik yang timbul pada lansia adalah kulit wajah, leher, lengan dan tangan menjadi kering dan keriput, masalah persendian terutama bagian tungkai dan lengan, menurunnya fungsi pendengaran dan penglihatan. Kemunduran psikologis yang sering dijumpai pada lansia antara lain perasaan tidak berguna, mudah sedih, insomnia, stress, depresi, ansietas, dan demensia. Salah satu gangguan yang terjadi pada lansia adalah Insomnia. Insomnia merupakan gangguan tidur yang cukup banyak terjadi pada orangtua. Sekitar $40 \%$ penderita insomnia adalah orangtua berusia $\geq 60$ tahun (Linden 2008).

Berdasarkan pengamatan peneliti selama ini lansia yang ada dipanti werdha banyak yang mengatakan tidak bisa tidur, meskipun tidak ada hal hal yang dipikirkan, tetapi tetap saja tidak bisa tidur, menurut hasil wawancara beberapa lansia mereka hanya tidur siang 1 jam dan malam 3 jam sehingga bila dilihat kebutuhan lansia seharusnya 6-8 jam tidak tercapai dengan baik hal ini juga terlihat secara fisik pada kondisi lansia diantarnya terlihat lansia itu loyo, menguap terus dan ada warna kehitaman dikelopak mata bagian bawah. Terapi musik adalah sebuat terapi kesehatan yang menggunakan musik di mana tujuannya adalah untuk meningkatkan atau memperbaiki kondisi fisik, emosi, kognitif, dan sosial bagi individu dari berbagai kalangan usia. Musik bisa menyentuh individu secara fisik, psikososial, emosional dan spiritual (Campbell, 2006). Musik keroncong khususnya keroncong abadi merupakan salah satu musik yang dapat digunakan dalam terapi musik, kelebihan dari musik ini adalah memiliki irama yang lembut dan alunan tempo yang lamban, sehingga bisa membuat pendengarnya merasa tenang dan tenggelam bersama alunan musik tersebut. Begitu pula dengan musik jawa yang mempunyai alunan tempo lamban dan syaduh.

Menurut data DEPKES RI tahun 2019 menunjukkan bahwa di Indonesia jumlah penduduk lansia sebanyak 18 juta jiwa $(7.56 \%)$, mengalami peningkatan sebanyak 25,9 juta jiwa (9,7\%). Menurut BPS (Badan Pusat Statistik) Jawa Timur memiliki jumlah penduduk lansia sebanyak $13.6 \%$, sedangkan di surabaya sendiri sebanyak $9.16 \%$. Prevalensi insomnia di Indonesia pada lansia tergolong tinggi yaitu sekitar $67 \%$ dari populasi yang berusia diatas 65 tahun. Hasil penelitian (Puspitosari, 2011) dalam (Sumitra, 2014) didapatkan insomnia sebagian besar dialami oleh perempuan yaitu sebesar $78,1 \%$ dengan usia 60-74 tahun.sedangkan di panti werdha didapatkan jumlah lansia 20, yang mengalami insomnia 17 lansia.

Insomnia merupakan suatu kondisi seseorang yang mengalami kesulitan tidur, atau mudah terbangun dan tidak dapat tidur lagi. Dampak dari insomnia pada lansia dapat mengakibatkan perubahan pada kehidupan sosial, psikologi dan fisik. Selain akan berdampak pada ekonomi dimana hilangnya produktivitas. Insomnia 
dapat meningkatkan risiko penyakit generatif seperti hipertensi dan jantung, depresi dan stress juga merupakan manifestasi dari insomnia pada lansia (Ghaddafi, 2010). Selain itu insomnia meningkatakn resiko jatuh pada lansia (Helbig, 2013). Beberapa gangguan tidur dapat mengancam jiwa baik secara langsung (misalnya insomnia yang bersifat keturunan dan fatal dan apnea tidur obstruktif) atau secara tidak langsung misalnya kecelakaan akibat gangguan tidur. Melihat permasalahan tersebut diatas maka ada berbagai cara dapat dilakukan untuk menurunkan insomnia pada lansia, di antaranya dengan terapi farmakologi dan non farmakologi. Terapi non farmakologi diantaranya adalah dengan olahraga teratur menggunakan wewangian aromaterapi dalam kamar dan mendengarkan alunan musik landai sebelum tidur. Pendapat ahli menyarankan untuk tidak menggunakan jenis musik tertentu seperti pop, disco, rock and roll, dan musik berirama keras lainnya, karena jenis-jenis musik tersebut merupakan irama yang berlawanan dengan irama jantung. Musik Keroncong dan Musik jawa juga dapat membawa lansia mengenang masa lalu yang dapat menghibur dan meningkatkan gairah hidup sehingga dapat meningkatkab gairah hidup sehingga dapat meningkatkan relaksasi (Amir, 2007). Hal ini disebabkan musik keroncong dan musik jawa bersifat nyaman, menenangkan, membuat rileks, berstruktur dan universal. Sebagai contoh : nafas kita, detak jantung, dan pulsasi semuanya berualang dan berirama seperti musik keroncong dan musik jawa. Terapi musik dapat dilakukan sebelum tidur selama 10-30 menit (Setyoadi Kushariyadi, 2011). Musik keroncong dan musik jawa dipilih oleh peneliti karena berirama landai, menenangkan dan mempunyai intrumentalia teratur.

\section{METODE}

Rancangan penelitian yang digunakan dalam penelitian ini adalah bersifat Pra experimental (pre-post design). Pada penelitian ini, populasinya adalah sebanyak 12 orang. Sampel di ambil dari sebagian dari sebagian lansia yang mengalami insomnia di Panti Werda Griya Surabaya. Penelitian ini menggunakan.

\section{HASIL}

Data ini menggambarkan tentang distribusi responden berdasarkan data demografi yang meliputi umur, jenis kelamin, pendidikan dan status perkawinan.

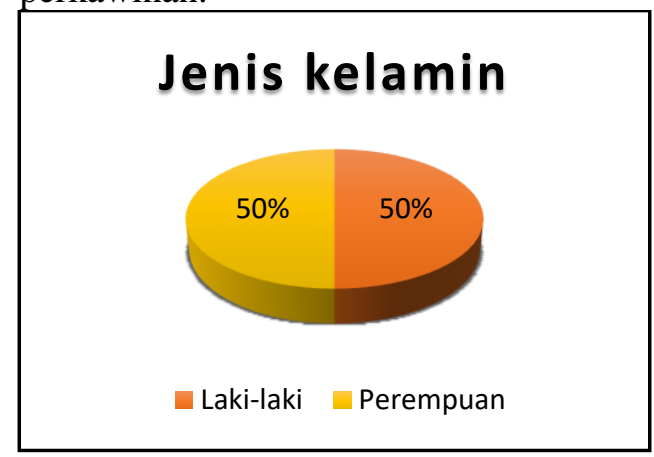

Gambar 1 : Diagram pie distribusi responden berdasarkan umur di Panti Werdha Griya Jambangan Surabaya

Berdasarkan diagram diatas, menunjukan bahwa responden berjumlah sama yaitu perempuan 6 orang (50\%) dan laki-laki 6 orang (50\%).

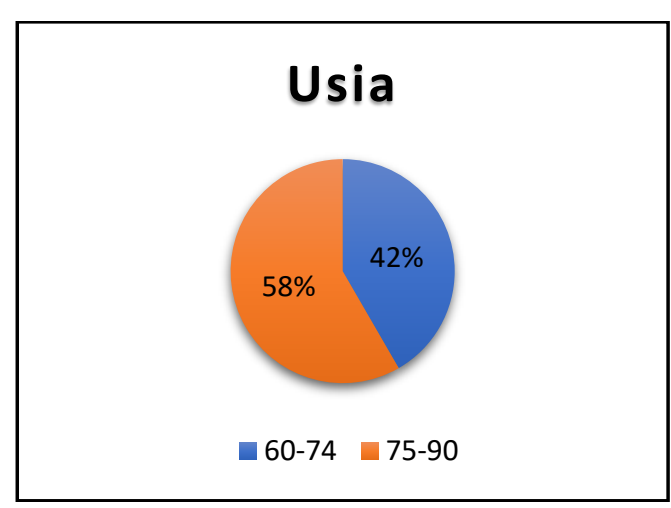

Gambar 2 : Diagram pie distribusi responden berdasarkan umur di panti Werdha griya jambangan

Berdasarkan diagram pie diatas menunjukan responden terbanyak adalah usia 75-90 tahun (58.33\%), dan terendah berusia 60-74 tahun (41.67\%). 


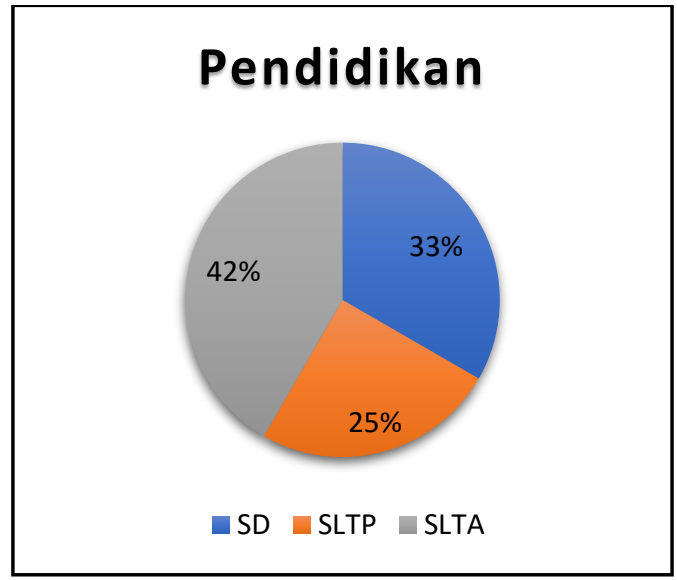

Gambar 3 : Diagram pie distribusi responden berdasarkan Pendidikan di panti Werdha griya jambangan.

Berdasarkan diagram pie di atas di dapatkan sebagian responden adalah berpendidikan SLTA 5 orang (41.67\%), dan yang terendah adalah SLTP 3 orang $(25 \%)$.

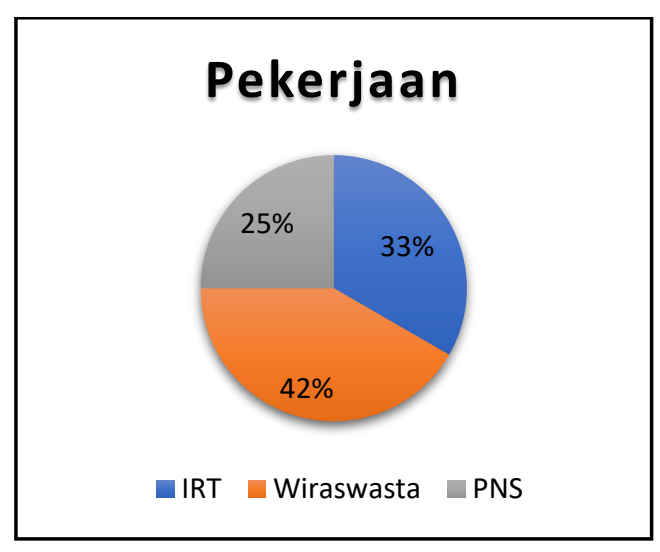

Gambar 4 : Diagram pie distribusi responden berdasarkan Pekerjaan di panti Werdha griya jambangan.

Berdasarkan diagram pie di atas, didapatkan sebagian responden yaitu sebagai pekerja swasta 5 orang (41.67\%), IRT 4 (33.33\%), dan wiraswasta 3 (25\%).

Distribusi data mengetahui hasil terapi musik keroncong dan musik jawa terhadap tingkat insomnia pada lansia di Panti Werdha Griya Jambangan Surabaya. Hasil tingkat insomnia sebelum diberikan terapi musik keroncong dan terapi musik jawa.

Tabel 1. Distribusi data sebelum dan sesudah di berikan terapi musik keroncong

\begin{tabular}{|c|c|c|c|c|c|c|}
\hline \multirow{2}{*}{ No } & \multirow{2}{*}{$\begin{array}{l}\text { Kriteria } \\
\text { Insomnia }\end{array}$} & \multicolumn{2}{|c|}{ Pretest } & \multirow{2}{*}{$\begin{array}{c}\text { Perilaku } \\
\text { Musik }\end{array}$} & \multicolumn{2}{|c|}{ Postest } \\
\hline & & $\mathbf{F}$ & $\%$ & & $\mathbf{F}$ & $\%$ \\
\hline 1 & Insomnia berat & 6 & $\begin{array}{c}100 \\
\%\end{array}$ & Keroncong & 0 & 0 \\
\hline 2 & $\begin{array}{l}\text { Insomnia } \\
\text { sedang }\end{array}$ & 0 & 0 & Keroncong & 1 & $\begin{array}{l}17 \\
\%\end{array}$ \\
\hline \multirow[t]{3}{*}{3} & $\begin{array}{l}\text { Insomnia } \\
\text { ringan }\end{array}$ & 0 & 0 & Keroncong & 5 & $\begin{array}{l}83 \\
\%\end{array}$ \\
\hline & Total & 6 & 100 & & 6 & 100 \\
\hline & & & & \multicolumn{3}{|c|}{$\mathrm{P}=0,027$} \\
\hline
\end{tabular}

Dari hasil uji statistik wilcoxon didapatkan hasil $\mathrm{p}=0,000$ dengan kemaknaan $\mathrm{p}<0,05$ yang berarti $\mathrm{H} 0$ ditolak dan Ha diterima, sehingga terdapat pengaruh antara pre test dan post test pada terapi musik keroncong pada lansia yang mengalami insomnia di Panti Werdha Griya Jambangan Surabaya.

Tabel 1. Distribusi data sebelum dan sesudah di berikan terapi musik jawa

\begin{tabular}{clccccc}
\hline \multirow{2}{*}{ No. } & \multirow{2}{*}{$\begin{array}{c}\text { Kriteria } \\
\text { Insomnia }\end{array}$} & \multicolumn{2}{c}{ Pretest } & $\begin{array}{c}\text { Perilak } \\
\mathbf{u}\end{array}$ & \multicolumn{2}{c}{ Postest } \\
\cline { 3 - 7 } 1 & F & $\%$ & Musik & F & $\%$ \\
\hline \multirow{2}{*}{1} & $\begin{array}{l}\text { Insomnia } \\
\text { berat }\end{array}$ & 4 & $\begin{array}{c}67 \\
\%\end{array}$ & Jawa & 1 & $\begin{array}{c}17 \\
\%\end{array}$ \\
\hline 2 & $\begin{array}{l}\text { Insomnia } \\
\text { sedang }\end{array}$ & 2 & $\begin{array}{c}33 \\
\%\end{array}$ & Jawa & 2 & $\begin{array}{c}33 \\
\%\end{array}$ \\
\hline 3 & $\begin{array}{l}\text { Insomnia } \\
\text { ringan }\end{array}$ & 0 & 0 & Jawa & 3 & $\begin{array}{c}50 \\
\%\end{array}$ \\
\hline & Total & 6 & 100 & & 6 & 100 \\
\hline \multicolumn{5}{c}{$\mathrm{P}=0.068$} \\
\hline
\end{tabular}

Dari hasil uji statistik wilcoxon didapatkan hasil $\mathrm{p}=0,068$ dengan kemaknaan $\mathrm{p}<0,05$ yang berarti $\mathrm{H} 0$ dan Ha diterima sehingga terdapat perbedaan antara pre test dan post test pada terapi musik keroncong pada lansia yang mengalami insomnia di Panti Werdha Griya Jambangan Surabaya.

\section{PEMBAHASAN}

$$
\text { Efektifitas terapi musik }
$$
keroncong dan musik jawa terhadap insomnia pada lansia sebelum diberikan terapi musik keroncong dan musik jawa di Panti Werdha Griya Jambangan Surabaya

Berdasarkan tabel 1 pada responden yang diberikan terapi musik keroncong didapatkan hasil dari responden yang 
mengalami insomnia berat sejumlah 6 lansia $(100 \%)$ setelah dilakukan terapi musik keroncong lansia yang mengalami perubahan menjadi insomnia sedang 1 lansia (17\%) dan lansia yang mengalami perubahan menjadi insomnia ringan 5 lansia (83\%). Lansia yang masih mengalami insomnia sedang, lansia mengeluh susah tidur sekitar 6-15 menit, dan bangun lebih awal 1 jam lebih cepat dari biasanya dan tidak dapat tidur kembali sehingga pemenuhan kebutuhan lansia terganggu. Berdasarkan hasil uji statistik Wilcoxon didapatkan hasil $\mathrm{p}=$ 0,027 dengan kemaknaan $\mathrm{p}<0,05$ yang berarti H0 ditolak dan $\mathrm{Ha}$ diterima, sehingga terdapat pengaruh antara pre test dan post test pada terapi musik keroncong pada lansia yang mengalami insomnia di Panti Werdha Griya Jambangan Surabaya. Menurut Setyoadi Kushariyadi (2011) cara yang digunakan dalam terapi musik keroncong adalah para responden dilakukan intervensi terapi musik keroncong selama 1 minggu (10-30 menit sebelum tidur). Terapi musik yang efektif menggunakan music dengan komposisi yang tepat antara beat, ritme dan harmony yang disesuaikan dengan tujuan. Jadi memang terapi musik yang efektif tidak bisa menggunakan sembarang musik. Musik keroncong adalah jenis musik paling tinggi yang dapat mempengaruhi otak menjadi lebih rileks, sehingga dapat membuat para responden tanpa bersusah payah untuk memulai tidur dan akan menjadi lebih terlelap saat tidur. Berdasarkan fakta dan teori terdapat kesamaan bahwa terapi musik keroncong berpengaruh terhadap tingkat insomnia pada lansia, hal ini didukung dengan hasil observasi didapatkan responden terlihat lebih rileks, jumlah jam tidur hampir mencapai normal dan lansia mengatakan bangun tidur terasa segar.

Berdasarkan tabel 2 pada responden yang diberikan terapi musik jawa didapatkan hasil dari responden yang mengalami insomnia berat 4 lansia $(67 \%)$ dan insomnia sedang 2 lansia (33\%) setelah diberikan terapi musik jawa didapatkan 1 lansia tidak mengalami perubahan 1 lansia (17\%), insomnia sedang 2 lansia (33\%), dan insomnia ringan 3 lansia (50\%). Lansia yang tidak mengalami perubahan mengeluh susah tidur, mudah terbangun saat malam dan susah untuk tidur kembali. Berdasarkan hasil uji statistik Wilcoxon didapatkan hasil $p=0,068$ dengan kemaknaan $p>0,05$ yang berarti $\mathrm{HO}$ diterima, sehingga tidak terdapat pengaruh antara pre test dan post test pada terapi musik jawa pada lansia yang mengalami insomnia di Panti Werdha Griya Jambangan Surabaya.

Menurut Purwadi (2006) menjelaskan bahwa musik gamelan jawa adalah musik yang dihasilkan dari seperangkat instrumen yang sering disebut sebagai istilah karawitan. Seni karawitan jawa mengandung nilai-nilai histori dan filosofis Bangsa Indonesia khususnya bagi masyarakat jawa dan karawitan jawa juga mempunyai fungsi estetika yang berkaitan dengan nilai-nilai sosial, moral dan spiritual. Karakteristik musik jawa untuk tempo lambat antara 60-100 (beats per menite) bpm dan pada tempo cepat antara 200-240 bpm. Musik gamelan tempo lambat memiliki ketukan hampir sama dengan musik Mozart yaitu dengan tempo kurang lebih 60 ketukan/menit. lansia. Hal ini bisa mendorong untuk menjadikan musik instrumental tradisional jawa seperti music keroncong sebagai terapi untuk mengurangi gangguan tidur salah satunya yaitu insomnia (Wijayanti, 2012). Berdasarkan fakta dan teori yang didapatkan kesamaan bahwa terapi musik jawa berpengaruh terhadap tingkat insomnia pada lansia. Hal ini didukung dengan hasil observasi, insomnia pada lansia mengalami penurunan dan lansia merasa lebih rileks karena musik jawa mempunyai nada slendro yang mempunyai alunan yang lembut dan menenangkan, meskipun ada 1 lansia yang mengalami insomnia berat karena beliau berasal dari NTT, menurut responden dia tidak mengerti dengan musik jawa sehingga hasilnya tetap insomnia berat. 


\section{SIMPULAN}

Terapi musik keroncong berpengaruh terhadap lansia yang mengalami insomnia di Panti Werdha Griya Jambangan Surabaya.

Terapi musik jawa berpengaruh terhadap lansia yang mengalami insomnia di Panti Werdha Griya Jambangan Surabaya.

Terapi musik keroncong lebih efektif dibandingkan terapi musik jawa pada lansia yang mengalami insomnia di Panti Werdha Griya Jambangan.

\section{SARAN}

Dengan adanya penelitian ini, diharapakan dapat meningkatkan pelayanan kesehatan di Panti Werdha Griya Jambangan khususnya pada lansia yang mengalami insomnia berat ataupun sedang dengan pemberian terapi musik keroncong setidaknya 1 minggu sekali saat lansia akan tidur pada malam hari atau saat lansia mengalami insomnia selama 10-30 menit

Bagi institusi pendidikan diharapkan hasil penelitian ini dapat digunakan sebagai pertimbangan untuk dijadikan salah satu referensi di perpustakaan Stikes William Booth Surabaya khususnya pada mata kuliah Gerontik ataupun keperawatan keluarga dengan anggota keluarga yang memiliki lansia dengan insomnia.

\section{DAFTAR PUSTAKA}

Adesla, V 2009, Gangguan Tidur, diakses 23 Desember 2019, (http://www.emedicinehealth.co m/gangguantidur/article.hmt)

Asmadi, 2008, Teknik Prosedural Keperawatan: Konsep dan Aplikasi Kebutuhan Dasar Klien. Jakarta: Salemba Medika.

Bandiyah, S 2009, Lanjut Usia dan Keperawatan Gerontik, Nuha Medika, Yogjakarta

Darmojo, RB \& Martono, HH 2004, Geriatri (Ilmu Kesehatan Usia Lanjut), Edisi 3, Balai Penerbit FKUI, Jakarta

Darmono \& Martono, 2010, Buku Ajar Geriatri (Ilmu Kesehatan Usia Lanjut). Jakarta: Balai Penerbit
FKUI

Darmojo, 2005, Proses Menua Dan Implikasi Kliniknya. Buku Ajar Penyakit Dalam Jilid I (ed. 5), Fakultas Kedokteran UI, Jakarta

Devi Sutra Mawar, 2019, Pengaruh Terapi Musik Langgam Jawa Terhadap Kualitas Tidur Pada Lansia., diakses 10 September 2019

Djohan, 2009. Terapi Musik dan Teori Aplikasi. Yogyakarta: Galang Press

Djohan, 2009. Psikologi Musik. Yigyakarta: Galang Press

Guyton, 2007, Aktivitas Otak-Tidur. Dalam Buku Ajar Fisiologi kedokteran-ed.9. Jakarta: EGC.

Nursalam (2011). Konsep Dan Penerapan Metodelogi Penelitian Ilmu keperawatan. Edisi 3. Jakarta : Salambe Medika

Javasugar 2009, Terapi Musik 1, diakses $12 \quad$ November 2019, (http://www.dechacare.com/terapi$\underline{\text { musik) }}$

Maryam, S dkk 2008, Mengenal Usia Lanjut dan Perawatannya, Salemba Medika, Jakarta

Pandeirot M. Nancye, Hendro Djoko TJ, 2017. Pengaruh Musik Keroncong Terhadap Tingkat Insomnia Pada Lansia.

Widya 2010, Mengatasi Insomnia, Katahati, Jogjakarta 